\title{
Integrated Eco-Friendly Outdoor Cooling System - Case Study of Hot-Humid Climate Countries
}

\author{
Mohammad Bani Khalid', Nabil Beithou ${ }^{1,2}$, M.A. Sh. Al-Taani ${ }^{3}$, \\ Artur Andruszkiewicz ${ }^{4}$, Ali Alahmer ${ }^{2}$, Gabriel Borowski ${ }^{5}$, Sameh Alsaqoor ${ }^{2 *}$ \\ 1 Department of Mechanical and Industrial Engineering, Applied Science Private University, P.O. Box 166, \\ 11931, Amman, Jordan \\ 2 Department of Mechanical Engineering, Tafila Technical University, P. O. Box 179, 66110, Tafila, Jordan \\ 3 Department of Architecture, Al-Albayt University, P. O. Box 130040, 25113, Mafraq, Jordan \\ ${ }^{4}$ Department of Thermal Science, Wrocław University of Science and Technology, Wybrzeże Wyspiańskiego \\ 27, 50-370, Wrocław, Poland \\ ${ }^{5}$ Faculty of Environmental Engineering, Lublin University of Technology, Nadbystrzycka 40B, 20-618 Lublin, \\ Poland \\ * Corresponding author's e-mail: sameh@wp.pl
}

\begin{abstract}
This research proposed an integrated eco-system for conditioning an outdoor public area (park or sport) in a hothumid environment. It is accomplished by the use of a dehumidifier control machine driven by renewable solar power; after which air is distributed throughout a ducting system. The system will harvest moisture from the air, utilize it for drinking water production and plants irrigation as well as deliver low temperature, low humidity ratio air for controlling the outdoor air, which results in a comfortable outdoor relative humidity and temperature $\left(24^{\circ} \mathrm{C}, 50 \% \mathrm{RH}\right)$. The Integrated Eco-Friendly Cooling System (IEFCS) is a sustainable self-dependent in energy and water sources. It provides a positive impact on the microclimate of the site, assists in night illumination, supplies water for drinking, plant irrigation, and allows people to enjoy a thermally comfortable atmosphere. The advantages include low maintaining cost as well as the possibility to be scaled and implemented anywhere according to the selected location.
\end{abstract}

Keywords: hot climate countries, open area, air conditioning, micro-climate, humidity control, recreation areas.

\section{INTRODUCTION}

Outdoor cooling is a hard task, as no boundaries are predetermined. Most of the outdoor cooling techniques have a passive nature [Kaboré et al. 2018, Santamouris et al. 2017]; vegetation and planting are frequently used to control the microclimate of a semi-open space. Cooling microclimate using passive cooling elements (PCEs) in the semi-outdoor space of a passive house located in one of the Japan's hottest cities was performed [Del Rio et al. 2020]. Controlling the outdoor air temperature relative humidity and purity is a challenging task for engineers. Hot dry climates are usually controlled by passive cooling or radiative cooling techniques, evaporative cooling also can be used, such as using water pools or spry cooling. Evaporative cooling will always be a favorable solution when the outside humidity is low [Kim \& Jeong 2013, Kim et al. 2014]; however, where space is close to sea, this technique should be avoided. Hot humid climates are of special interest; radiative and evaporative cooling may increase the relative humidity and thus prevent achieving comfort conditions. The area of interest in this work involves the Arabian Gulf Countries (AGC), which are characterized by a hot-humid climate (HHC). Even though mist spray cooling [Ulpiani 2019] is used in Macca during the Pilgrimage season as an effective 
cooling technique, the area is quite large and the number of people in active simultaneous motion reaches millions. Limited hot humid areas for sports or recreation activities may have a better solution that cools the space and reduce its relative humidity. Passive-evaporative cooling will make the case worse because of the high relative humidity in humid areas [Hui \& Cheung 2009, Doulos et al. 2004, Vangtook \& Chirarattananon 2007]. Many researchers noted that humidity is not the only factor affecting the outdoor microclimate control, since the energy saving and type of energy used are also relevant [Hong Yuping et al. 2008, Chàfer et al. 2020]. Recently, the outdoor air conditioning received a huge interest as the world cup organizing activity was assigned to one of the Gulf countries, i.e. Qatar. Qatar is a country with hot-humid climate that will host the world cup in 2022. Qatar suffered a lot from extreme climate and worked to solve this problem using huge air conditioning devices that blow air from hundreds of openings in the space [Matzarakis \& Fröhlich 2014, Budaiwi \& Abdou 2000]. Such a technique consumes huge amounts of energy and costs a lot of money. As Qatar is an oil-producing, rich country, this technique was applicable, but of course it is not a worldwide applicable solution. In hot-humid climates planting trees will reduce the air temperature as well as increase the relative humidity, which is not adequate. There is a need to cool air and reduce its relative humidity to provide comfortable conditions for people. The idea of this project is based on using renewable solar energy umbrellas to collect the energy required to drive a (WGA) machine which in turn produces the air with a low temperature low humidity ratio. This selfdependent system will remove moisture from air as well as supply fresh water for drinking and plant irrigation. In addition, it will supply the air characterized by low temperature and low humidity ratio that will exchange heat with the air entering the machine, which will then be mixed with the outdoor air to achieve the suitable relative humidity and temperature $\left(24^{\circ} \mathrm{C}, 50 \% \mathrm{RH}\right)$.

\section{METHODOLOGY}

\section{Site Characteristics}

The investigated site is a desert landscape characterized by hot-humid air conditions and high solar intensity. Thus, the sand temperature is very high, reaching about $60^{\circ} \mathrm{C}$, and air temperature may reach $47^{\circ} \mathrm{C}$ with up to $70-80 \%$ relative humidity. Such climate is common in the Arab Gulf sea side cities, including Abu Dhabi, Dubai, Jeddah, Bahrain, Aqaba and Kuwait [American Society of Heating, Refrigerating and Air-Conditioning Engineers, 2017]. Figure 1 shows a typical site used in the project implementation. The site has been randomly selected from Jeddah city Saudi Arabia through Google Earth.

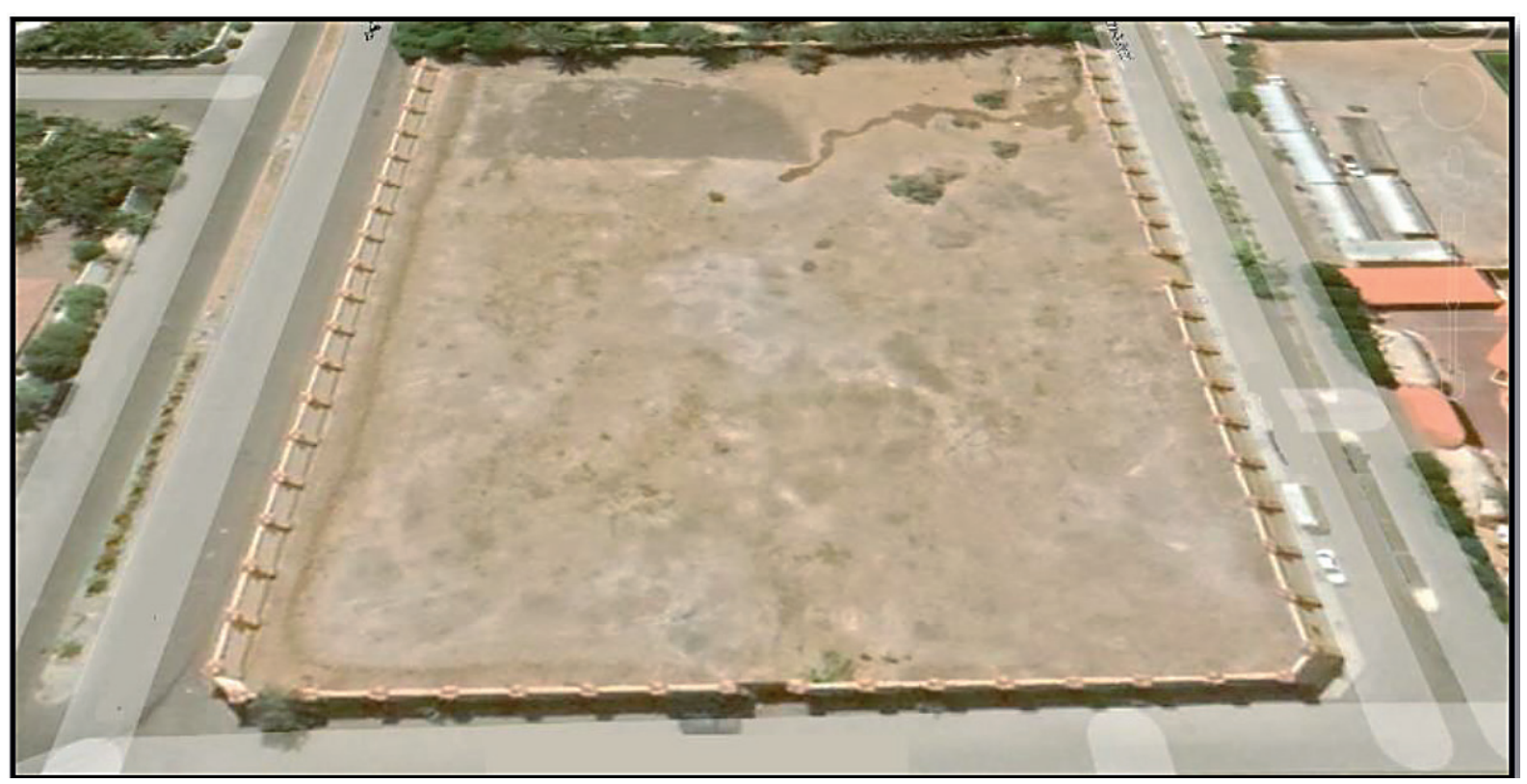

Figure 1. Sample site from Jeddah City, Saudi Arabia (Google Earth) 


\section{Site problem}

Figure 1 depicts a location where high temperatures and high relative humidity restrict individuals from engaging in daytime activities such as sports or relaxation. It is well-known that departments of municipalities in each city are striving to provide people with recreation parks in each sub-area of the city. The high temperature and high relative humidity make such option impossible except in closed areas. The use of closed area all the time may create health and psychological problems. In order to overcome such a problem, an integrated eco-friendly outdoor cooling system is proposed to make the desert land with hot-humid weather a comfortable area for sports or recreation during day and night time.

\section{Proposed site solution}

Changing the country's environment, of course, is not an option. Engineers can only manipulate the microclimate of the site, which may be accomplished by lowering both the temperature and relative humidity of the site using an integrated ecofriendly cooling system, as illustrated in Figure 2. The following are the major system components:

a) Smart Solar Umbrellas that monitor the sun Photovoltaic (PV) devices in the shape of a rose offer both shade and DC electricity to an inverter, which generates $\mathrm{AC}$ power. Batteries are used to store extra power for nighttime lights.

b) Machine extracting water from the air: is a vapor compression machine that employs a refrigeration cycle to cool the evaporator, which extracts water vapor from the air, resulting in a low temperature-low humidity ratio in the released air. To raise the temperature of the machine, the expelled air exchanges heat with the air entering it (heat recovery).

c) Air mixing and distribution system: controlled mixing of medium temperature-low relative humidity air with outdoor high relative humidity-high temperature air to achieve air within the human comfort zone. To keep the site temperature within the desired range, this comfortable air is circulated by ducts and diffusers from decorative locations.

d) Trees and plants: according to the site objectives, the trees and plants are planted to provide extra shading and an attractive view.

The operating premise of IEFCS begins with the use of abundant high-intensity solar energy in these nations as a source of energy, which is gathered using Smart Solar Umbrellas (SSU). SSU converts solar energy into electrical energy and provides shade to the designated place. The electrical energy generated by SSU is utilized by the Water Generation Machine (WGM) to condense

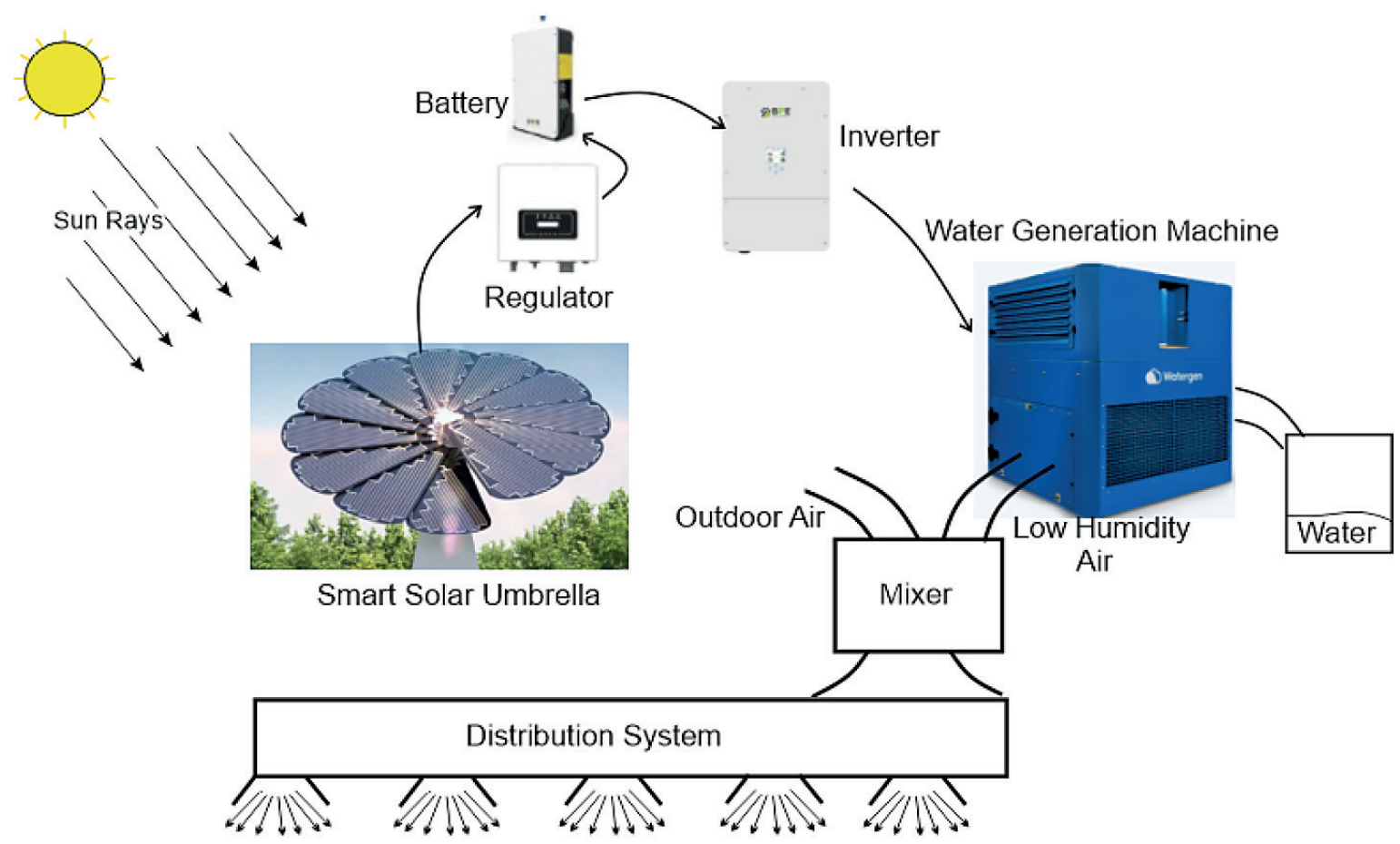

Figure 2. The integrated eco-friendly cooling system 
water vapor from the air, lowering its humidity ratio. WGM produces low-temperature, low-humidity air. This air is then mixed with outside air to make the air that is within the human comfort zone. Trees and plants growing well in hot, humid regions are adopted.

\section{SYSTEM COMPONENTS}

\section{Smart solar umbrella}

SSU is a sun-tracking solar PV system (smart flower) made up of twelve solar cells stacked on individual "petals". Figure 3 a depicts a solar flower (SF) that blooms like a flower at the start of each day and closes at nightfall. In addition to solar cells, the SF system has a dual-axis tracker, which allows its petals to track the Sun across the sky throughout the day. The 12-petal, $18-\mathrm{m}^{2}$ structure generates $2.5 \mathrm{~kW}$ of electricity.

SFs are considered to be the main source of energy for this system. The specifications of SSU or SF are given in Table 1.

This system should be sized to drive the water generation from air machine (WGM) - displayed in Figure 3b.

\section{Water generation from air machine}

The produced electrical power from the SF system will supply a regulator to control the voltage before entering the storage battery. An inverter will be used to invert the DC power from battery to AC power as shown in Figure 2. This AC power will drive WGM.

Many approaches, including adsorption, absorption, and vapor compression refrigeration

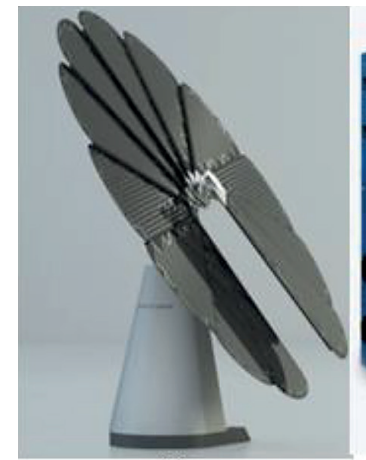

(a)

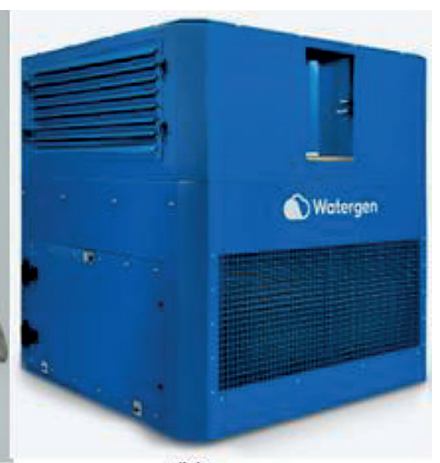

(b)
Figure 3. Smart flower solar PV system (a), water generation machine (b) techniques, were employed in the literature to condense water from ambient air and generate cooling from solar energy [Baakeem et al. 2019, Alahmer et al. 2018, Alahmer \& Ajib 2020, Alahmer et al. 2020, Alahmer et al. 2019, Ajib \& Alahmer 2018]. WGM is a system that uses refrigeration cycle to lower the temperature of air flowing over a specially designed evaporator of the refrigeration cycle. It allows higher contact between air and evaporator surfaces; air reaches the dew point temperature and condenses on the evaporator surfaces. The machine results in liquid water and low-temperature/low-humidity air which will be used to cool the outdoor space. The selected WGM for this study is shown in Figure $3 b$. The technical specifications are given in Table 2 .

Figure $3 \mathrm{~b}$ shows a WGM that produces pure drinking water from the humidity in the air. The machine is energy-efficient and economically feasible. WGM requires only electricity to function; there is no need for plumbing or infrastructure. With electrical supply, WGM produces up to 800 liters of clean, safe drinking water per day.

\section{Air mixing and distribution system}

The system shown in Figure 4 is a sketch for the air mixing-distribution system, used to distribute air all over the outdoor area for microclimate control. This air distribution system (ADS) depends largely upon the outdoor land usage. In the case of a park, diffusers may be placed below

Table 1. Technical and physical specification of the solar flower

\begin{tabular}{|l|c|}
\hline Nominal output & $2.50 \mathrm{kWp}$ \\
\hline Temperature range & $-25{ }^{\circ} \mathrm{C}$ to $50{ }^{\circ} \mathrm{C}$ \\
\hline Weight & $\sim 766 \mathrm{~kg}$ \\
\hline Area & $18 \mathrm{~m}^{2}$ \\
\hline Wind speed & $48 \mathrm{~km} / \mathrm{h}$ \\
\hline Expected life & 25 years \\
\hline
\end{tabular}

Table 2. Technical specifications of the GEN-M machine used in this study

\begin{tabular}{|l|c|}
\hline Length $x$ width $x$ height & $1.4 \times 1.4 \times 1.58 \mathrm{~m}$ \\
\hline Weight & $780 \mathrm{~kg}$ \\
\hline Production capacity per day & $550 \mathrm{~L}\left(26^{\circ} \mathrm{C}, 60 \% \mathrm{RH}\right)$ \\
\hline Power consumption (nominal) & $5.6 \mathrm{~kW}$ \\
\hline Energy efficiency $\left(26^{\circ} \mathrm{C}, 60 \% \mathrm{RH}\right)$ & $350 \mathrm{Wh} / \mathrm{L}$ \\
\hline Refrigerant & $\mathrm{R} 410 \mathrm{~A}$ \\
\hline
\end{tabular}




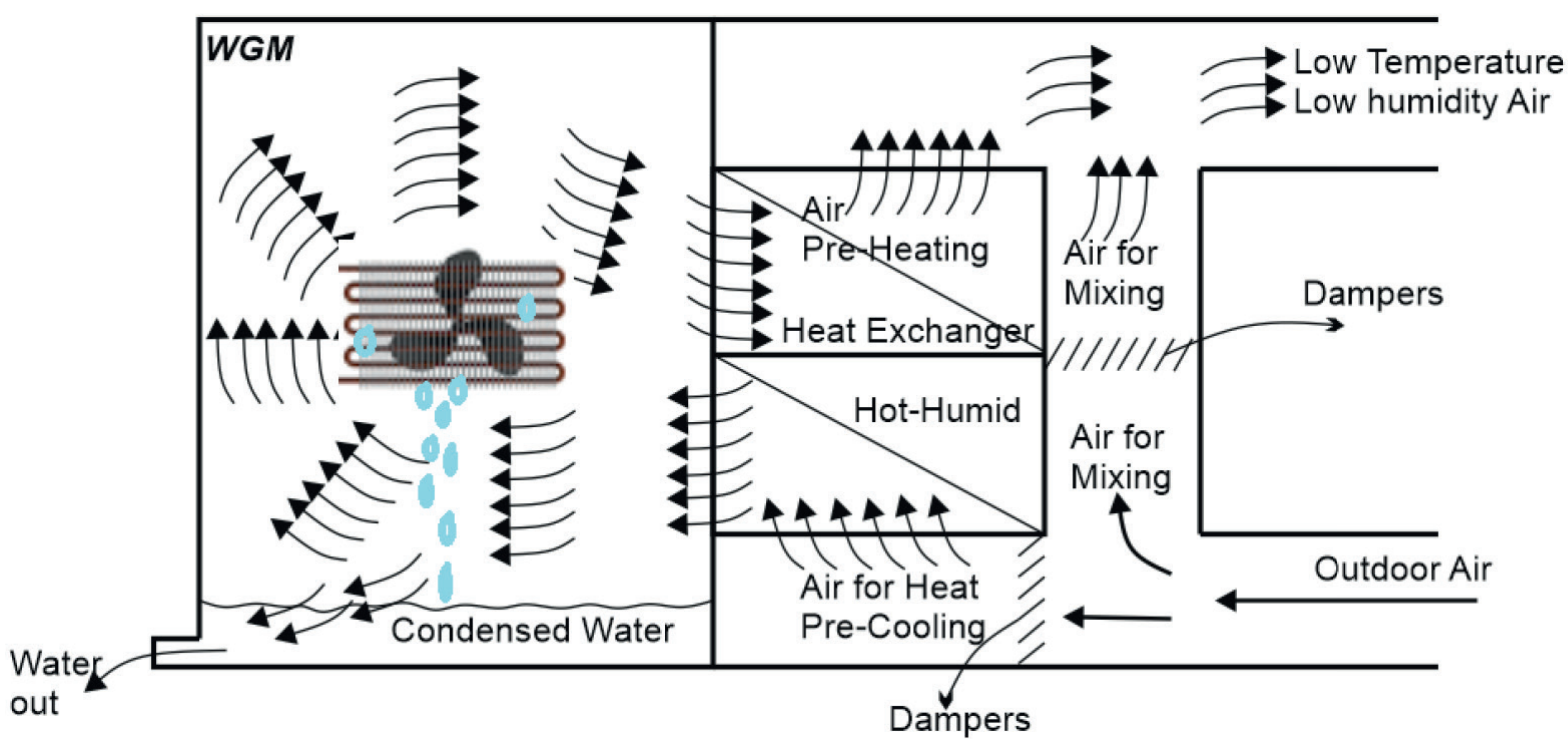

Figure 4. A sketch for air mixing-distribution system

the umbrellas and beneath the seats throughout the park area, if a sport region is considered, air may be distributed around the area of the playground. Nevertheless, the air distribution system is highly sensitive to the case studied, it depends on the shape, purpose and ambient conditions of the site.

\section{Trees and plants}

Trees and plants play a great role in landscaping; they are the foundation of most landscape plantings. Several factors influence the choice of plants, including function required, weather conditions and human relaxation. Generally, landscape must be designed to be attractive and beneficial, with fairly low-maintenance. The bellshaped flowers in Figure 5a are rose to purple in color, highly adoptable to hot-humid climates, bearing fruits which are round in structure. The plant was chosen for its growth up to a height of 8-9 meters, climbers, extenders and suitability to hot humid climates. It is to be located on walls and fences, blocking unwanted views in the park.

Vernonia Elaeagnifolia is commonly known as curtain creeper and is a climber. Vernonia climbs up and then falls down beautifully over a wall or railing. It is a foliage plant, grown primarily for its habit of forming a green curtain. The plant was selected for its abilities to survive in hot humid climates. Royal Palm Figure 5b was selected to be located in different positions of the landscape. Palm tree is one of the most sought-after landscape palms for their eventual large size.

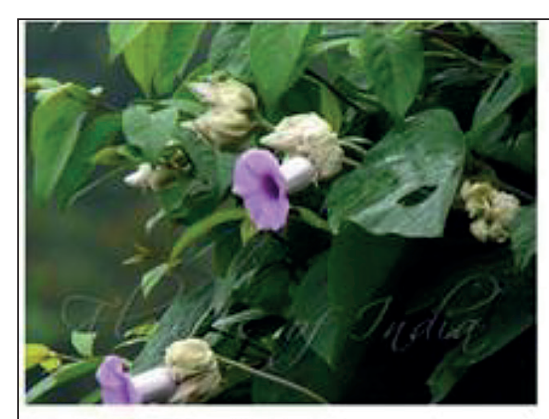

Common name: elephant creeper Botanical name: Argyreia nervosa

Height: about $7 \mathrm{~cm}$

Use: gardens

Climate: hot and humid

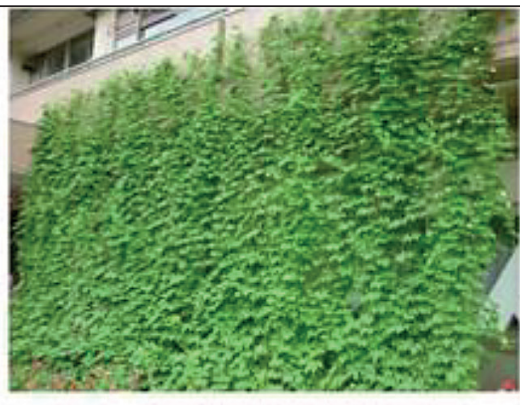

Common name: curtain creeper Botanical name: Vemonia elaeagnifolia Height: about 1.2 to $1.8 \mathrm{~m}$ Use: gardens

Climate: hot and humid

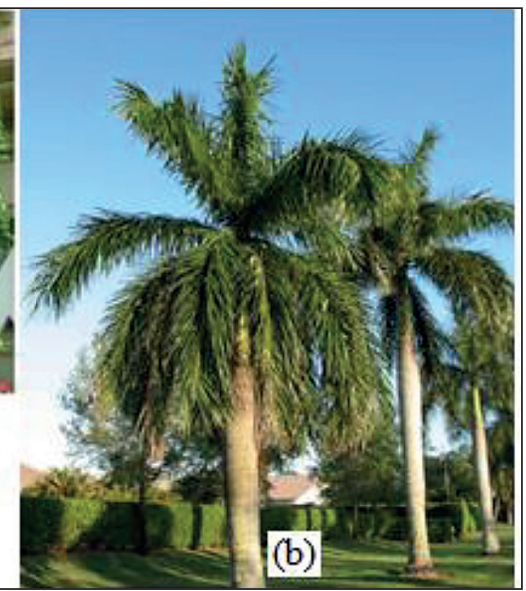

Figure 5. (a) Trees and plants used in hot-humid climate, (b) Royal palms (Roystonea regia) for hot-humid climates 


\section{RESULTS OF CALCULATIONS}

\section{System sizing for the selected site}

The size of the solar flower and accompanying water generating equipment from air must be sized according to the area of the site and its air conditions (T, RH). Jeddah in Saudi Arabia was taken as a sample city for our case study. The monthly average minimum and maximum temperatures are given in Figure 6A, whereas the monthly relative humidity data are presented in Figure 6B. WGM is explained in section 4.1.2, Figure $3 \mathrm{~b}$; its production rate is $550 \mathrm{~L} /$ day, $5.6 \mathrm{~kW}$ power consumption and $350 \mathrm{Wh} / \mathrm{L}$ as energy efficiency, the COP of the machine can be evaluated as follows:

Hourly production rate $=$

$$
=H P R=\frac{550}{24}=22.91 \mathrm{~L} / \mathrm{h}
$$

Cooling Energy =

$$
=C E=22.91 * 350=8020.8 \mathrm{~W}
$$

While Machine Consumed Electrical Power (MCEP) is $5.6 \mathrm{~kW}$, as given in Table 2, then COP is,

$$
C O P=\frac{C E}{M C E P}=\frac{8.0208}{5.6}=1.432
$$

The working mechanism of the proposed system combined with the air handling unit (AHU) is illustrated in Figure 7, where the WGM is integrated with the ADS, air enters the system at point 1 , exchange of heat occurs in a closed $\mathrm{HE}$ lowering its temperature from 1 to 2 and raising the supply temperature from point 4 to 5 . The heat exchanger is assumed to be adiabatic; all heat lost from the first flow is transferred to the second flow. The heat exchanger effectiveness may be used to count for losses.

Air mass conservation

$$
\dot{m}_{a 1}=\dot{m}_{a 2}=\dot{m}_{a 3}=\dot{m}_{a 4}=\dot{m}_{a 5}
$$

Processes 1-2 and 4-5 in the heat exchanger, sensible heat transfer

$$
\begin{gathered}
\dot{m}_{a 2} h_{1}-\dot{Q}=\dot{m}_{a 1} h_{2} \\
\dot{m}_{a 4} h_{4}+\varepsilon \dot{Q}=\dot{m}_{a 5} h_{5}
\end{gathered}
$$

where: $\varepsilon$ is heat exchanger effectiveness defined as

$$
\varepsilon=\left(T_{5}-T_{4}\right) /\left(T_{1}-T_{2}\right)
$$
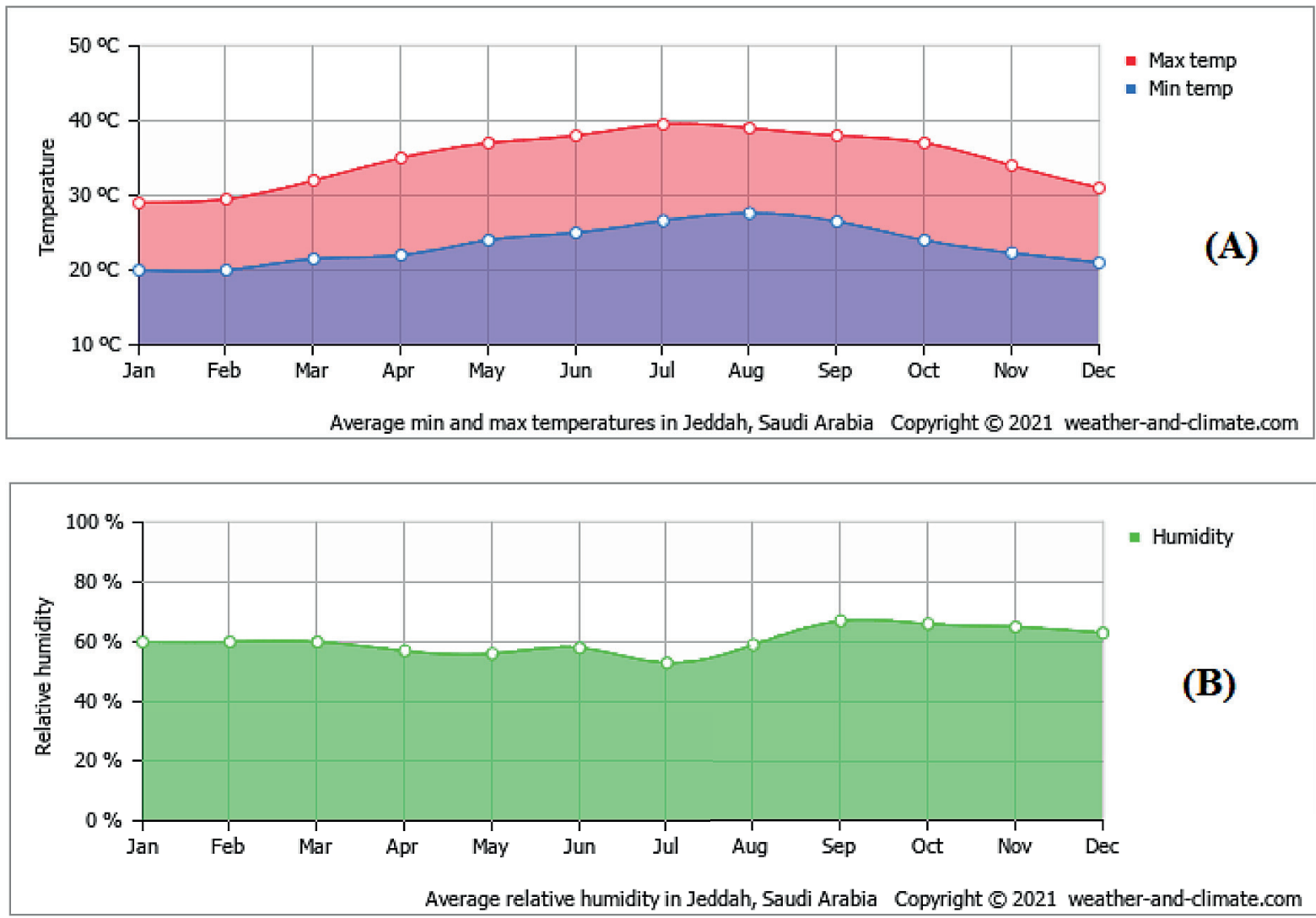

Figure 6. Monthly average $\min / \max$ temperatures (A) and average relative humidity in Jeddah (B) 


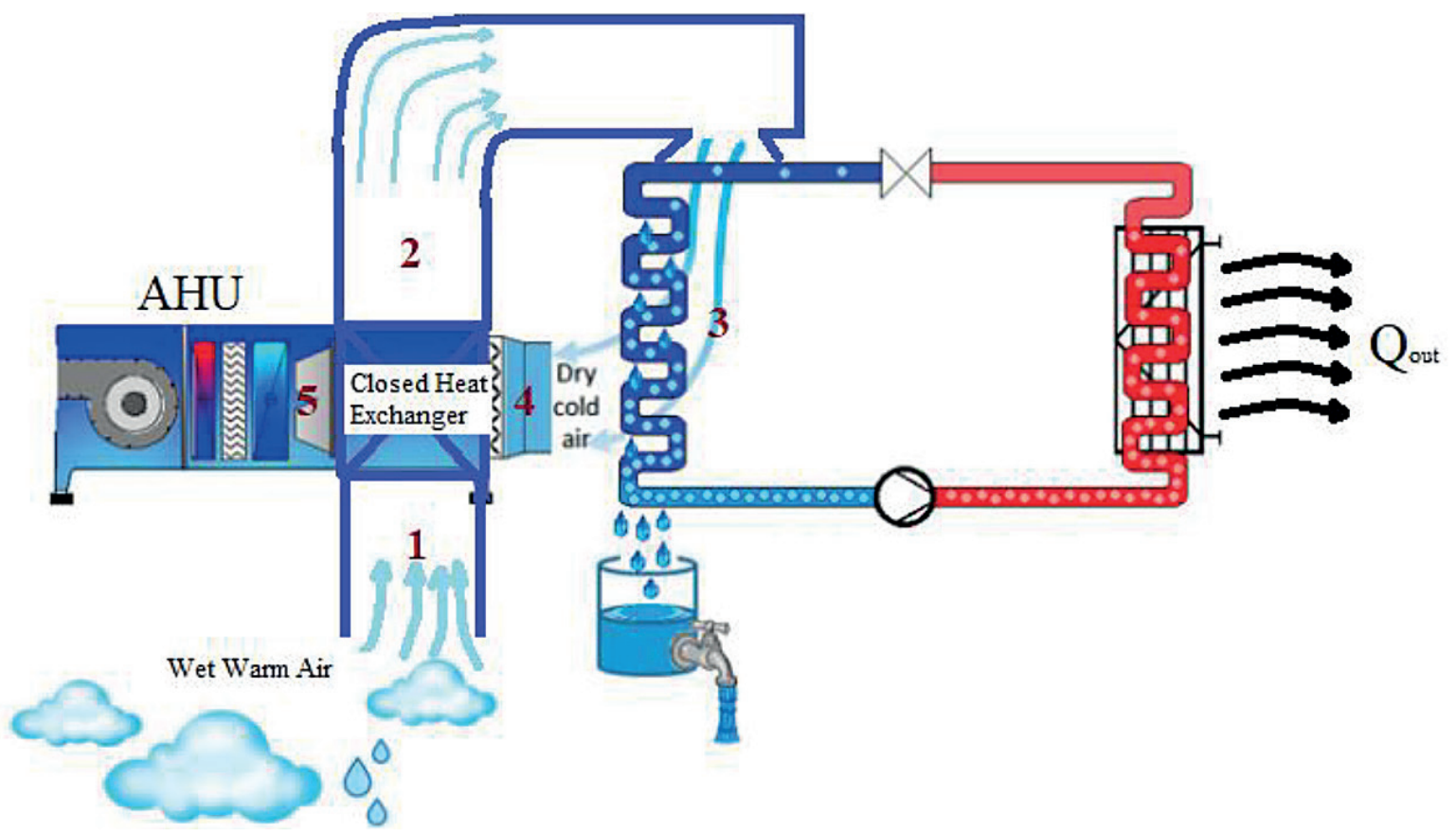

Figure 7. Schematic diagram of the WGM with ADS, heat recovery mode [Cattani et al. 2021]

Process 3-4 is governed by mass (both air and water) in addition to energy conservations,

Air mass conservation

$$
\dot{m}_{a 3}=\dot{m}_{a 4}
$$

Water mass conservation

$$
\dot{m}_{a 3} w_{3}-\dot{m}_{w}=\dot{m}_{a 4} w_{4}
$$

Energy conservation

$$
\dot{m}_{a 3} h_{3}-\dot{Q}_{r}-\dot{m}_{w} h_{f}=\dot{m}_{a 4} h_{4}
$$

For mixing purposes after heat recovery,

$$
\dot{m}_{a m 1} h_{m 1}+\dot{m}_{a m 2} h_{m 2}=\dot{m}_{a m T} h_{m T}
$$

\section{Validating the used integrated system}

Each WGM consumes $5.6 \mathrm{~kW}$ of power, whereas each SF produces $2.5 \mathrm{kWp}$. This indicates that nearly three SFs are required to power one WGM, with a matching solar PV system size of $54 \mathrm{~m}^{2}$ (Table 1). The occupied zone for comfort control is $30 \times 40 \times 2.5 \mathrm{~m}$, and the air volume covering the conditioned outside area is $30 \times 40 \times 2.5 \mathrm{~m}$. As a result, the volume is $3000 \mathrm{~m}^{3}$. When this park is busy, the ventilation can range from 3-10 $\mathrm{ACH}$. The lowest value will be considered in this study; however, greater values may be utilized if the design criteria require it. In this study, the air volume flow rate is assumed to be the ventilation flow rate $\left(9000 \mathrm{~m}^{3} / \mathrm{h}\right)$ of three ACHs. Table 3, shows the monthly moist air properties in Jeddah.

Calculating the estimated exit enthalpy using the WGM with a $9000 \mathrm{~m}^{3} / \mathrm{h}$ air flow rate, $29^{\circ} \mathrm{C}$, and $60 \% \mathrm{RH}$, one machine will not be capable of extracting water, but it will be capable of reducing the temperature of the air to around $25-26^{\circ} \mathrm{C}$. The issue is characterized by a low sensible heat ratio (SHR), with space transfers of around $70 \mathrm{~kW}$ latent and $15 \mathrm{~kW}$ sensible to the outside air. To minimize the humidity ratio of the supplied air, a large cooling load will be

Table 3. Monthly moist air properties in Jeddah

\begin{tabular}{|c|c|c|c|c|c|c|c|c|c|c|c|c|}
\hline Jeddah & Jan & Feb & Mar & Apr & May & Jun & Jul & Aug & Sep & Oct & Nov & Dec \\
\hline DBT C & 29 & 30 & 32 & 34 & 37 & 38 & 40 & 39 & 38 & 37 & 34 & 31 \\
\hline $\mathrm{RH} \%$ & 60 & 60 & 60 & 57 & 56 & 59 & 51 & 60 & 68 & 65 & 64 & 62 \\
\hline $\mathrm{Tdp} \mathrm{C}$ & 20 & 21 & 24 & 24 & 26 & 28 & 27 & 29 & 31 & 29 & 26 & 22 \\
\hline $\mathrm{w} \mathrm{kg} / \mathrm{kg}$ & 0.0151 & 0.0160 & 0.0191 & 0.0192 & 0.0223 & 0.0249 & 0.024 & 0.0268 & 0.0289 & 0.0261 & 0.0216 & 0.0175 \\
\hline $\mathrm{h} \mathrm{kJ/kg}$ & 67.8 & 71.2 & 82.1 & 83.4 & 94.7 & 102.4 & 102 & 108.4 & 112.7 & 104.3 & 89.7 & 76.2 \\
\hline $\mathrm{Twb} \mathrm{C}$ & 22 & 23 & 25 & 26 & 28 & 29 & 29 & 30 & 31 & 30 & 27 & 24 \\
\hline $\mathrm{v} \mathrm{m}^{3} / \mathrm{kg}$ & 0.88 & 0.88 & 0.89 & 0.9 & 0.91 & 0.92 & 0.92 & 0.92 & 0.92 & 0.92 & 0.9 & 0.89 \\
\hline
\end{tabular}




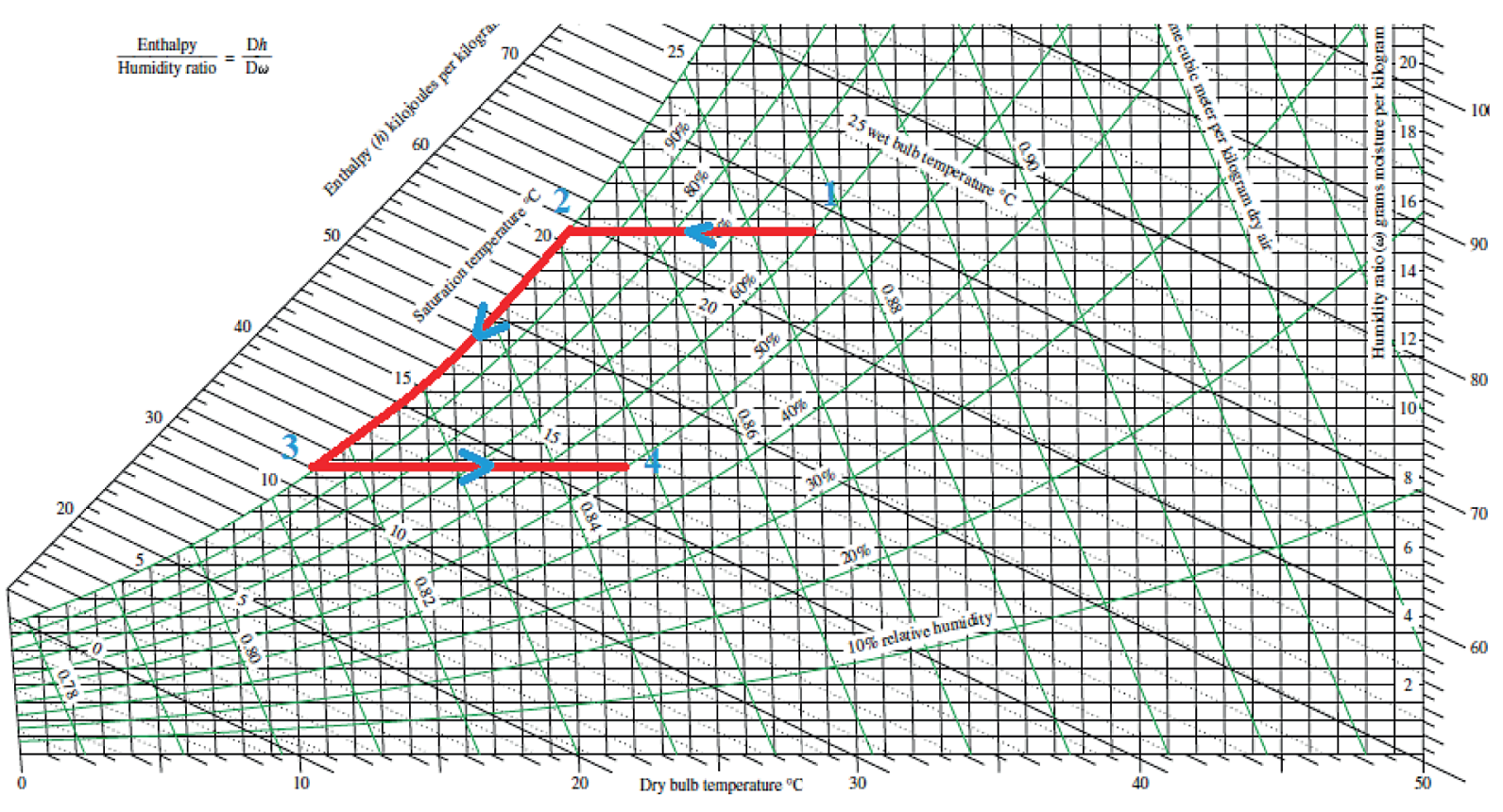

Figure 8. Psychrometric chart showing the initial and final expected processes (1-4) ideally

necessary. By performing system calculations, it was determined that each machine will need 0.065 $\mathrm{kg} / \mathrm{s}$ of airflow rate, while a total of $0.83 \mathrm{~kg} / \mathrm{s}$ is necessary to condition the region; this means that 13 WGMs and around 30 SFs should be employed. The total area required for such a system is around $500 \mathrm{~m}^{2}$, which accounts for $40 \%$ of the conditioned area. Such a system will be capable of lowering the outside air temperature and relative humidity from $42{ }^{\circ} \mathrm{C}$ and $80 \% \mathrm{RH}$ to $10{ }^{\circ} \mathrm{C}$ and from $43 \mathrm{gw} / \mathrm{kga}$ to $7.5 \mathrm{gw} / \mathrm{kga}$. The system will continually deliver $106 \mathrm{~kg}$ of water each hour.

The conditioned air will be blown into the site and mixed with the site air; the new space temperature and relative humidity may then be measured and utilized as input values to the WGM.

On the psychrometric chart, Figure 8 depicts the processes for lowering the temperature and relative humidity of the location. More realistic data with accounting to heat losses and instantaneous mixing processes with heat recovery necessitate a simultaneous simulation of the given system, which will be the part of future extensive investigations of the suggested system.

\section{CONCLUSIONS}

The Integrated Eco-Friendly cooling system is a sustainable solution, self-dependent in terms of energy and water sources. It has a favorable influence on the site's microclimate, aids in night illumination, offers water for drinking and plant irrigation, and allows people to enjoy thermally pleasant air in an open space. This project has the advantages of having a high CCF, low maintaining cost, producing plenty of clean water, and providing almost full shading. The system can accommodate any architecturally added designs, be deployed anywhere, and be scaled to fit the allotted space.

\section{Acknowledgments}

The authors are grateful to the Applied Science Private University, Amman, Jordan, and to the Tafila Technical University, Tafila, Jordan, for the financial support granted to this research.

\section{REFERENCES}

1. Kaboré, M., Bozonnet, E., Salagnac, P., \& Abadie, M. (2018). Indexes for passive building design in urban context - indoor and outdoor cooling potentials. Energy and Buildings, 173, 315-325. doi:10.1016/j. enbuild.2018.05.04.

2. Santamouris, M., Ding, L., Fiorito, F., Oldfield, P., Osmond, P., Paolini, R., Synnefa, A. (2017). Passive and active cooling for the outdoor built environment - Analysis and assessment of the cooling potential of mitigation technologies using performance data from 220 large scale projects. Solar Energy, 154, 14-33. doi:10.1016/j.solener.2016.12.006.

3. Del Rio, M. A., Asawa, T., \& Hirayama, Y. (2020). Modeling and Validation of the Cool 
Summer Microclimate Formed by Passive Cooling Elements in a Semi-Outdoor Building Space. Sustainability, 12(13), 5360. doi:10.3390/su12135360 .

4. Kim, M.-H., \& Jeong, J.-W. (2013). Cooling performance of a $100 \%$ outdoor air system integrated with indirect and direct evaporative coolers. Energy, 52, 245-257. doi:10.1016/j.energy.2013.02.008.

5. Kim, M.-H., Park, J.-Y., Park, J.-S., \& Jeong, J.-W. (2014). Application of desiccant systems for improving the performance of an evaporative cooling-assisted $100 \%$ outdoor air system in hot and humid climates. Journal of Building Performance Simulation, 8(3), 173-190. doi:10.1080/19401493.2014.899395.

6. Ulpiani, G. (2019). Water mist spray for outdoor cooling: A systematic review of technologies, methods and impacts. Applied Energy, 254, 113647. doi:10.1016/j.apenergy.2019.11364

7. Hui, S. C. M. and Cheung, W. Y., (2009). Two-stage evaporative cooling systems in hot and humid climate, In Proceedings of the Tianjin-Hong Kong Joint Symposium 2009, 29-30 Jun 2009, Tianjin, China, pp. 64-76.

8. Doulos, L., Santamouris, M., \& Livada, I. (2004). Passive cooling of outdoor urban spaces. The role of materials. Solar Energy, 77(2), 231249. doi:10.1016/j.solener.2004.04.005

9. Vangtook, P., \& Chirarattananon, S. (2007). Application of radiant cooling as a passive cooling option in hot humid climate. Building and Environment, 42(2), 543-556. doi:10.1016/j.buildenv.2005.09.0

10. Hong Yuping, Ji Shengqin, Zhang Yunhui, Kong Xiaoming, Chen Qiao, Cucchietti, F., \& Gianluca Griffa. (2008). Energy saving active cooling systems for outdoor cabinet. INTELEC 2008 - 2008 IEEE 30th International Telecommunications Energy Conference. doi:10.1109/intlec.2008.4664063

11. Chàfer, M., Pisello, A. L., Piselli, C., \& Cabeza, L. F. (2020). Greenery System for Cooling Down Outdoor Spaces: Results of an Experimental Study. Sustainability, 12(15), 5888. doi:10.3390/su12155888.
12. Matzarakis, A., \& Fröhlich, D. (2014). Sport events and climate for visitors - the case of FIFA World Cup in Qatar 2022. International Journal of Biometeorology, 59(4), 481-486. doi:10.1007/ s00484-014-0886-5 .

13. Budaiwi, I. M., \& Abdou, A. A. (2000). Energy and thermal performance of heatpipe/cooling coil systems in hot-humid climates. International Journal of Energy Research, 24(10), 901-915. doi:10.1002/1099114x(200008)24:10<901::aid-er632>3.0.co;2-s .

14. American Society of Heating, Refrigerating and Air-Conditioning Engineers. 2017. ASHRAE handbook: Fundamentals: SI edition. Atlanta, GA: ASHRAE..

15. Baakeem, S. S., Orfi, J., Mohamad, A., \& Bawazeer, S. (2019). The possibility of using a novel dew point air cooling system (M-Cycle) for $\mathrm{A} / \mathrm{C}$ application in Arab Gulf Countries. Building and Environment, 148, 185-197. doi:10.1016/j.buildenv.2018.11.00.

16. Alahmer, A., Al-Dabbas, M., Alsaqoor, S., \& AlSarayreh, A. (2018). Utilizing of solar energy for extracting freshwater from atmospheric air. Applied Solar Energy, 54(2), 110-118.

17. Alahmer, A., \& Ajib, S. (2020). Solar cooling technologies: State of art and perspectives. Energy Conversion and Management, 214, 112896.

18. Alahmer, A., Wang, X. \& Alam, K.C. (2020). Dynamic and economic investigation of a solar thermal-driven two-bed adsorption chiller under Perth climatic conditions. Energies, 13(4), 1005.

19. Alahmer, A., Alsaqoor, S. \& Borowski, G. (2019). Effect of parameters on moisture removal capacity in the desiccant cooling systems. Case Studies in Thermal Engineering, 13, 100364.

20. Ajib, S. \& Alahmer, A., (2018). Solar Cooling Technologies. In Energy Conversion-Current Technologies and Future Trends. IntechOpen.

21. Cattani, L., Magrini, A., \& Cattani, P. (2021). Water Extraction from Air: A Proposal for a New Indicator to Compare Air Water Generators Efficiency. Energies, 14(1), 224. doi:10.3390/en14010224. 